\title{
Sistem Pendukung Keputusan Pemilihan Penyidik Pegawai Negeri Sipil (PPNS) dengan Menggunakan Metode Electre Studi Kasus: Balai Wilayah Sungai Sumatera II Medan
}

\author{
Delvi Sitinjak \\ Program Studi Teknik Informatika, STMIK Budi Darma, Medan, Indonesia \\ Email: delvisitinjak27@gmail.com
}

\begin{abstract}
Abstrak-Penyidik Pegawai Negeri Sipil merupakan salah satu aparat penegakan hukum yang memiliki fungsi untuk melakukan proses penyidikan yang diberi wewenang khusus untuk melakukan proses penyidikan terhadap suatu pelanggaran Produk Hukum pemerintahan Daerah (PERDA) yang mengandung unsur tindak pidana. Biasanya tindak pidana tersebut bukan tindak pidana umum yang bisa ditangani oleh penyidik kepolisian. Dalam pengambilan keputusan pemilihan Penyidik pegawai Negeri Sipil (PPNS) di Balai Wilayah Sungai Sumatera II Medan penulis menggunakan metode Electre, Dimana Electre adalah salah satu metode penentuan urutan atau prioritas dalam MCDM (Multi-Criterion Decision Making). Pada penggunaan Sistem pendukung keputusan dengan metode Electre akan memberikan nilai rating kecocokan untuk setiap alternatif. Didalamnya semua data digabung menjadi satu dengan bobot penilaian yang telah diperoleh melalui penilaian tes. Penulis mencoba merancang dan membangun sistem pendukung keputusan pemilihan Penyidik pegawai negeri Sipil dengan menggunakan metode Electre, menyediakan informasi yang dibutuhkan oleh panitia dalam pengambilan keputusan dan menerapkan Metode Electre dalam menentukan Penyidik pegawai Negeri Sipil Balai Wilayah Sungai Sumatera II Medan Sistem pendukung keputusan bukan merupakan alat pengambilan keputusan, melainkan merupakan sistem yang membantu pengambil keputusan dengan melengkapi mereka dengan informasi dari data yang telah di olah dengan relevan dan diperlukan untuk membuat keputusan tentang suatu masalah dengan lebih cepat dan akurat.
\end{abstract}

Kata Kunci: Pendukung Keputusan, Electre, Pemilihan ,Penyidik Pegawai, Negeri Sipil..

\begin{abstract}
The Civil Servant Investigator is one of the law enforcement officers that has the function to carry out an investigation process that is given special authority to carry out an investigation process for a violation of the Regional Government Legal Product (PERDA) which contains elements of criminal acts. Usually the crime is not a general crime that can be handled by police investigators. In making the decision on the selection of Civil Servant Investigators (PPNS) at the Medan Sumatera River Region II Medan the writer uses the Electre method, where Electre is one of the methods for determining the order or priority in MCDM (Multi-Criterion Decision Making). In the use of decision support systems with the Electre method will provide a matching rating value for each alternative. In it all data are combined into one with the weight of the assessment that has been obtained through test assessment. The author tries to design and build a decision support system for the selection of Civil Servant Investigators using the Electre method, providing information needed by the committee in making decisions and applying the Electre Method in determining the Civil Servant Investigator Balai Sumatera River Region II Medan Medan Decision support system is not a making tool decision, but rather a system that helps decision makers by equipping them with information from data that has been processed with relevance and is needed to make decisions about an issue more quickly and accurately.
\end{abstract}

Keywords: Decision Supporter, Electre, Election, Civil Servant Investigator.

\section{PENDAHULUAN}

Komputer merupakan suatu alat bantu manusia khusunya dalam bidang pekerjaan. Komputer bisa dipergunakan dalam bidang pemilihan penyidik pegawai negeri sipil khususnya di dalam instansi pemerintahan Balai Wilayah Sungai Sumatera II. Penyidik Pegawai Negeri Sipil merupakan salah satu aparat penegakan hukum yang memiliki fungsi untuk melakukan proses penyidikan yang diberikan wewenang khusus untuk melakukan proses penyidikan terhadap suatu pelanggaran Produk Hukum Pemerintahan Daerah (PERDA) yang mengandung unsur tindak pidana. Biasanya tindak pidana tersebut bukan tindak pidana umum yang bisa ditangani oleh penyidik kepolisian. Dalam menyelenggarakan tugas dan fungsi Penyidik Pegawai Negeri Sipil dibidang sumber daya air adalah: " Tersedianya infrastuktur Sumber Daya Air yang memadai sebagai sarana pendukung Mewujudkan kemanpaatan Sumber Daya Air yang berkelanjutan".

Dalam pengambilan keputusan pemilihan Penyidik pegawai Negeri Sipil (PPNS) di JL. AH Nasution No.30 Medan Balai Wilayah Sungai Sumatera II penulis menggunakan metode Electre, Dimana Electre adalah salah satu metode penentuan urutan atau prioritas dalam MCDM (Multi-Criterion Decision Making)[1]-[5].

Pada penggunaan Sistem pendukung keputusan dengan metode Electre akan memberikan nilai rating kecocokan untuk setiap alternatif. didalamnya semua data digabung menjadi satu dengan bobot penilaian yang telah diperoleh melalui penilaian tes[6]. Untuk pemilihan pegawai negeri sipil di Balai Wilayah sungai Sumatera II masih menggunakan sistem percatatan secara manal yaitu pertama dengan membuat surat edaran kepada seluruh penyidik pegawai negeri sipil tentang seleksi penyidik pegawai negeri sipil Balai Wilayah Sungai Sumatera II . kemudian oleh tim seleksi penyidik pegawai negeri sipil Balai Wilayah Sungai Sumatera II dikumpulkan untuk diteliti dan dikoreksi apakah penyidik pegawai tersebut layak menjadi penyidik pegawai negeri sipil di Balai Wilayah Sungai Sumatera II. Setelah didapat nama - nama penyidik pegawai negeri sipil yang layak untuk menjadi penyidik pegawai negeri sipil Balai Wilayah Sungai Sumatera II . kemudian nama - nama tersebut di rapatkan 
oleh para pejabat yang ada di Balai Wilayah Sungai Sumatera II Medan kemudian hasil rapat itulah yang dijadikan urutan dalam pemilihan penyidik pegawai negeri sipil yang nantinya akan diusulkan untuk menjadi penyidik pegawai negeri sipil di Balai Wilayah Sungai Sumatera II Medan. Pada sistem ini terdapat beberapa kesulitan yaitu dalam menentukan urutan penyidik pegawai negeri sipil, kemudian proses penentuan PPNS di Balai Wilayah Sungai Sumatera II yang memakan waktu cukup lama, lalu sering munculnya subjektivitas dari para pejabat pengambilan keputusan. Untuk menghindari hal - hal tersebut dalam mennetukan urutan PPNS Balai Wilayah Sungai Sumatera II yang sesuai dengan kriteria yang ditetapkan oleh An.kepala Balai Sungai Sumatera II.

Penulis mencoba menerapkan dan merancang aplikasi sistem pendukung keputusan pemilihan Penyidik pegawai negeri Sipil dengan menggunakan metode Electre, menyediakan informasi yang dibutuhkan oleh panitia dalam pengambilan keputusan dan menerapkan Metode Electre dalam menentukan Pemilihan Penyidik Pegawai Negeri Sipil Balai Wilayah Sungai Sumatera II Medan.

\section{METODE PENELITIAN}

\subsection{Penyidik Pegawai Negeri Sipil}

Penyidik Pegawai Negeri Sipil merupakan salah satu aparat penegakan hukum yang memiliki fungsi untuk melakukan proses penyidikan yang diberikan wewenang khusus untuk melakukan proses penyidikan terhadap suatu pelanggaran Produk Hukum Pemerintahan Daerah (PERDA) yang mengandung unsur tindak pidana. Biasanya tindak pidana tersebut bukan tindak pidana umum yang bisa ditangani oleh penyidik kepolisian. Dalam pasal 6 ayat 1 hurup b UU No.8 Tahun 1981 Tentang Hukum Acara Pidana PPNS (Penyidik Pegawai Negeri Sipil). dalam menyelenggarakan tugas dan fungsi Penyidik Pegawai Negeri Sipil dibidang sumber daya air adalah Tersedianya infrastuktur Sumber Daya Air yang memadai sebagai sarana pendukung Mewujudkan kemanpaatan Sumber Daya Air yang berkelanjutan[7].

\subsection{Elemination Et Choix Traduisant Ia Realite (ELECTRE)}

Electre merupakan salah satu metode pengambilan keputusan multi kriteria berdasrkan pada konsep Outranking dengan menggunakan perbandingan berpasangan dari alternatif-alternatif berdasarkan setiap kriteria yang sesuai. Metode Electre digunakan pada kondisi dimana alternatif yang kurang sesuai dengan kriteria dieliminasi, dan alternatif yang sesuai dapat dihasilkan[8]-[10]. Dengan kata lain, Electre digunakan untuk kasus-kasus dengan banyak alternatif namun hanya sedikit kriteria yang dilibatkan. Suatu alternatif dikatakan mendominsi alternatif yang lain jika satu atau lebih kriterianya melebihi (dibandingkan dengan kriteria dari alternatif yang lain) dan sama dengan kriteria lain yang tersisa.

Langkah - langkah yang dilakukan dalam penyelesaian masalah menggunakan metode Electre[11]-[14], sebagai berikut :

1. Normalisasi matriks keputusan

Dalam prosedur ini, setiap atribut diubah menjadi nilai coparable. Setiap normalisasi dari nilai xij dapat dilakukan dengan rumus:

$\mathrm{r}_{\mathrm{ij}}=\frac{x_{i j}}{\sqrt{\sum_{i=1}^{m} x^{2} i j}}$

untuk $\mathrm{i}=1,2,3 \ldots, \mathrm{m}$ dan $\mathrm{j}=1,2,3 \ldots, \mathrm{n}$. Sehingga didapat matriks $\mathrm{R}$ hasil normalisasi,

$\mathrm{R}=\left[\begin{array}{cccc}r_{11} & r_{12} & \cdots & r_{1 n} \\ r_{21} & r_{22} & \cdots & r_{2 n} \\ \vdots & r_{m 1} & \ldots & r_{m n}\end{array}\right]$

$\mathrm{R}$ adalah matriks yang telah dinormalisasikan, dimana m menyatakan alternatif, $\mathrm{n}$ menyatakan kriteria dan $\mathrm{r}_{\mathrm{ij}}$ adalah normalisasi pengukuran pilihan dari alternatif ke- $i$ dalam hubungannya dengan kriteria ke- $j$

2. Pembobotan pada matrik yang telah dinormalisasikan.

Setelah dinormalisasikan, setiap kolom dari matrik R dikalikan dengan bobot-bobot $\left(W_{j}\right)$ yang ditentukan oleh pembuat keputusan. Sehingga, weighted normalized matrix adalah $V=R . W$ yang ditulis dalam rumus :

$$
\left[\begin{array}{cccc}
v_{11} & v_{12} & \ldots & v_{1 n} \\
v_{21} & v_{22} & \ldots & v_{2 n} \\
\vdots & v_{m 2} & \ldots & v_{m n}
\end{array}\right]=\left[\begin{array}{cccc}
w_{1} r_{11} & w_{2} r_{12} & \ldots & w_{n} r_{1 n} \\
w_{1} r_{21} & w_{2} r_{22} & \ldots & w_{n} r_{2 n} \\
\vdots & v_{m 1} & \\
w_{1} r_{m 1} & w_{2} r_{m 2} & \ldots & w_{n} r_{m n}
\end{array}\right]
$$

$\operatorname{Dimana} W\left[\begin{array}{ccccc}v_{11} & 0 & 0 & \ldots & 0 \\ 0 & & & & \\ \vdots & w_{2} & 0 & \ldots & \\ 0 & 0 & 0 & \ldots & w_{n}\end{array}\right]$ 
3. Menentukan concordance dan discordance index

Untuk setiap pasangan dari alternatif $k$ dan $l(k, l=1,2,3, \ldots, \mathrm{m}$ dan $\mathrm{k} \# 1)$ kumpulan kriteria J dibagi menjadi dua subsets, yaitu concordance dan discordance. Bilamana sebuah kriteria dalam suatu alternatif termasuk concordance adalah:

$C_{k l}=\left\{J, y_{k j . .>y_{i j}}\right\}$, untuk $\mathrm{j}=1,2,3, \ldots, \mathrm{n}$

Sebaliknya, komplementer dari subnet ini adalah discordence, yaitu bila:

$D_{k l}=\left\{J, y_{k j . .>y_{i j}}\right\}$, untuk $\mathrm{j}=1,2,3, \ldots, \mathrm{n}$

3. Hitung matrik concordance dan discordance.

Concordance

Untuk menentukan nilai elemen-elemen pada matriks concordance adalah menjumlahkan bobot-bobot yang termasuk dalam subset concordance, secara matematisnya adalah pada Rumus

$C_{k l}=\sum_{j}^{n}{ }^{n} w_{j}$

Sehingga matrik concordance yang dihasilkan adalah:

$$
C=\left[\begin{array}{ccccc}
- & c_{12} & c_{13} & \ldots & c_{1 n} \\
c_{21} & - & c_{23} & \ldots & c_{2 n} \\
\cdots & - & & & \\
c_{m 1} & c_{m 2} & c_{m 3} & \ldots & -
\end{array}\right]
$$

Discordance.

Untuk menentukan nilai dari elemen-elemen pada matriks discordance. Adalah dengan membagi maksimum selisih nilai kriteria yang termasuk dalam subset discordance dengan maksimum selisih nilai seluruh kriteria yang ada, secara matematisnya adalah :

$d_{k l}=\left\{\max \left(v_{m n m n}^{-}-i n\right)\right\} ; \mathrm{m}, \mathrm{n} \in D_{k l}$

$d_{k l}=\left\{\max \left(v_{m n m n}^{-}-i n\right)\right\} ; \mathrm{m}, \mathrm{n}=1,2,3$,

Sehingga diperoleh matriks discordance:

$D=\left[\begin{array}{ccccc}- & d_{12} & d_{13} & \ldots & \\ d_{21} & - & d_{23} & \ldots & d_{2 n} \\ \cdots & & & & -\end{array}\right]$

4. Menentukan matrik dominan concordance dan discordance.

a. concordance

Matrik F sebagai dominan concordance dapat dibangun dengan bantuan nilai theshold, yaitu dengan membandingkan setiap elemen matriks concordance dengan nilai theshold. dengan nilai theshold $C_{k l} \geq c$ Dengan nilai theshold $(c)$ adalah:

$$
\mathrm{C}=\frac{\sum_{k=1}^{m} \sum_{i=1}^{m} C_{k l}}{\mathrm{~m}(\mathrm{~m}-1)}
$$

Sehingga elemen matriks F ditentukan sebagai berikut:

$$
f_{k}\left\{\begin{array}{l}
1, j i k a_{C_{k l} \geq_{c}} \\
0, j i k a_{C_{k l<c}}
\end{array}\right.
$$

b. Menentukan matriks dominan discordance untuk membangun matriks dominan discordance juga menggunakan bantuan nilai theshold, yaitu :

$D_{k l} \geq d$

Sehingga elemen matriks $\mathrm{G}$ ditentukan sebagai berikut:

$$
g_{k l}=\left\{\begin{array}{l}
1, j i k a_{d_{k l}<d} \\
0, j i k a_{k l c} \geq d
\end{array}\right.
$$

c. Menentukan aggregate dominace matriks langkah selanjutnya adalah menentukan aggregate dominace matrix sebagai matriks $F$ dengan elemen matriks $G$, sebagai berikut :

$E_{k l}=f_{k} X g_{k l}$

d. Eliminasi alternatif yang less favourable

Matriks E memberikan urutan pilihan dari setiap alternatif, yaitu bila ekl = 1 maka alternatif Ak merupakan pilihan yang lebih baik dari pada Al. Sehingga baris dalam matriks E yang memiliki ekl = 1 paling sedikit dapat dieliminasi. Dengan demikian alernatif terbaik adalah yang mendominasi alternatif lainya. 


\section{HASIL DAN PEMBAHASAN}

Penyidik Pegawai Negeri Sipil merupakan salah satu aparat penegakan hukum yang memiliki fungsi untuk melakukan proses penyidikan yang diberikan wewenang khusus untuk melakukan proses penyidikan terhadap suatu pelanggaran Produk Hukum Pemerintahan Daerah (PERDA) yang mengandung unsur tindak pidana. Biasanya tindak pidana tersebut bukan tindak pidana umum yang bisa ditangani oleh penyidik kepolisian. Dalam pasal 6 ayat 1 hurup b UU No.8 Tahun 1981 Tentang Hukum Acara Pidana PPNS (Penyidik Pegawai Negeri Sipil) Adalah Pejabat pegawai negeri sipil tertentu yang diberi wewenang khusus oleh undang-undang. Sedangkan dalam pasal 93 UU No 7 tahun 2004 pasal 93 tentang Kewenangan PPNS SDA

Dalam melaksanakan kewenangan berdasarkan Undang -Undang masing-masing. PPNS Menjalankan penyidikan berdasarkan PERDA tetapi berdasarkan kewenangan yang diberikan Undang-Undang spesifik masingmasing

Dalam melakukan Pemilihan penyidik Pegawai Negeri Sipil tersebut memiliki beberapa pertimbangan criteria yaitu loyalitas, kedisiplinan, jabatan, dan Pendidikan. Hal tersebut dianggap mampu mengukur seorang calon layak atau tidak untuk diangkat menjadi penyidik pegawai negeri sipil nantinya, disamping criteria tersebut diatas dibutuhkan juga dilakukan tes tertulis seperti, tes psikotest, dan akademik, sehingga didapatkan tim penyidik yang kompeten nantinya. Berikut ini Merupakan Tabel Daftar Alternatif yang akan dipilih sebagai berikut:

Tabel 1. Daftar Alternatif yang akan dipilih

\begin{tabular}{|c|c|c|c|c|c|c|}
\hline No & Nama & $\begin{array}{l}\text { Jenis } \\
\text { Kelamin }\end{array}$ & Pendidikan & Pengalaman & Kesehatan & Umur \\
\hline 1 & $\begin{array}{l}\text { Evan NI Siahaan } \\
\text { Xiv }\end{array}$ & $\mathrm{L}$ & $\mathrm{S} 2$ & 2 Tahun pengalaman kerja & Baik & 30 \\
\hline 2 & Titin Verianty & $\mathrm{P}$ & $\mathrm{S} 1$ & 1 Tahun pengalaman kerja & Baik & 28 \\
\hline 3 & Silvia Damayanti & $\mathrm{P}$ & D3 & 1 Tahun pengalaman kerja & Baik & 27 \\
\hline 4 & Aan Apriani & $\mathrm{P}$ & D3 & 1 Tahun pengalaman kerja & Baik & 27 \\
\hline 5 & Sunarto Suradi & $\mathrm{L}$ & $\mathrm{S} 1$ & 2 Tahun pengalaman kerja & Baik & 28 \\
\hline 6 & Fifin Safinti & & $\mathrm{S} 1$ & 3 Tahun Pengalaman kerja & Baik & 28 \\
\hline 7 & $\begin{array}{l}\text { Amru Pakpahan } \\
\text { Azkadina }\end{array}$ & $\mathrm{L}$ & $\mathrm{S} 2$ & 4 Tahun Pengalaman kerja & Baik & 30 \\
\hline 8 & $\begin{array}{l}\text { Alghassani Hadi } \\
\text { Hasibuan }\end{array}$ & $\mathrm{P}$ & $\mathrm{S} 2$ & 5 Tahun Pengalaman kerja & Baik & 30 \\
\hline 9 & M Fauzi Risky & $\mathrm{L}$ & $\mathrm{S} 1$ & 1 Tahun Pengalaman kerja & Baik & 40 \\
\hline 10 & Darman Syah & $\mathrm{L}$ & D3 & 3 Tahun Pengalaman kerja & Baik & 35 \\
\hline 11 & Mery Sihombing & $\mathrm{P}$ & $\mathrm{S} 2$ & 3 Tahun Pengalaman kerja & Baik & 33 \\
\hline 12 & Titin Pangaribuan & $\mathrm{P}$ & $\mathrm{S} 1$ & 5 Tahun Pengalaman kerja & Baik & 35 \\
\hline 13 & Chandra Maha & $\mathrm{L}$ & D3 & 3 Tahun Pengalaman kerja & Baik & 29 \\
\hline 14 & Juliadi Diduk & & $\mathrm{S} 1$ & 1 Tahun Pengalaman kerja & Baik & 28 \\
\hline 15 & Desy Lestari & $\mathrm{P}$ & D3 & 4 Tahun Pengalaman kerja & Baik & 43 \\
\hline 16 & Wahyu Suherdro & $\mathrm{L}$ & $\mathrm{S} 1$ & 4 Tahun Pengalaman kerja & Baik & 41 \\
\hline 17 & $\begin{array}{l}\text { Maria Chatherin } \\
\text { Sinurat }\end{array}$ & $\mathrm{P}$ & $\mathrm{S} 2$ & 4 Tahun Pengalaman kerja & Baik & 29 \\
\hline 18 & Ridwan Setiawan & $\mathrm{L}$ & $\mathrm{S} 2$ & 1 Tahun Pengalaman kerja & Baik & 37 \\
\hline 19 & Okto Immanuel & $\mathrm{L}$ & $\mathrm{S} 1$ & 1 Tahun Pengalaman kerja & Baik & 39 \\
\hline 20 & Putri Pohan & $\mathrm{P}$ & $\mathrm{S} 2$ & 2 Tahun Pengalaman kerja & Baik & 30 \\
\hline 21 & Abdul Gafur & $\mathrm{L}$ & $\mathrm{S} 2$ & 1 Tahun Pengalaman kerja & Baik & 31 \\
\hline 22 & Fandy Aria & $\mathrm{L}$ & D3 & 1 Tahun Pengalaman kerja & Baik & 30 \\
\hline 23 & Winda Maharani & $\mathrm{P}$ & $\mathrm{S} 1$ & 2 Tahun Pengalaman kerja & Baik & 29 \\
\hline 24 & Ifan Nasution & $\mathrm{L}$ & $\mathrm{S} 1$ & 1 Tahun Pengalaman kerja & Baik & 27 \\
\hline 25 & Onrizal & $\mathrm{L}$ & $\mathrm{S} 1$ & 2 Tahun Pengalaman kerja & Baik & 26 \\
\hline 26 & Henoch Ageri & $\mathrm{P}$ & $\mathrm{S} 2$ & 3 Tahun Pengalaman kerja & Baik & 33 \\
\hline 27 & Inswanto & $\mathrm{L}$ & $\mathrm{S} 2$ & 1 Tahun Pengalaman kerja & Baik & 30 \\
\hline 28 & Dicky Risand & $\mathrm{L}$ & S1 & 2 Tahun Pengalaman kerja & Baik & 32 \\
\hline
\end{tabular}

Sumber : Balai Wilayah Sungai Sumatera II, 2018

Electre merupakan salah satu metode pengambilan keputusan multi criteria berdasarkan pada konsep Outranking dengan menggunakan perbandingan berpasangan dari alternatif-alternatif berdasarkan setiap kriteria yang sesuai. Metode Electre digunakan pada kondisi dimana alternatif yang kurang sesuai dengan criteria dieliminasi, dan alternatif yang sesuai dapat dihasilkan. Dengan kata lain, Electre digunakan untuk kasus-kasus 
dengan banyak alternative namun hanya sediki tkriteria yang dilibatkan. Suatu alternative dikatakan mendominsi alternatif yang lain jika satu atau lebih kriterianya melebihi (dibandingkan dengan criteria dari alternatif yang lain) dan sama dengan kriteria lain yang tersisa. Adapun kriteria yang dinilai adalah sebagai berikut :

Tabel 2. Kriteria yang digunakan

\begin{tabular}{ll}
\hline & Keterangan \\
\hline $\mathrm{C} 1$ & Loyalitas \\
$\mathrm{C} 2$ & Kedisiplinan \\
$\mathrm{C} 3$ & Jabatan \\
$\mathrm{C} 4$ & Pendidikan \\
\hline
\end{tabular}

Untuk melakukan pemilihan penyidik pegawai negeri sipil maka diperlukan sebuah olahan data dengan menerapkan metode ELECTRE dalam melakukan penyelesaiannya. Data mentah yang digunakan nantinya terlebih dahulu dilakukan konversi berdasarkan bobot preferensi. Berikut ini adalah asumsi dari penilaian setiap kriteria yang digunakan:

Tabel 3. Bobot Preferensi

\begin{tabular}{cl}
\hline No & Predikat \\
\hline 1 & Buruk \\
2 & Cukup \\
3 & Baik \\
4 & Sangat Baik \\
\hline
\end{tabular}

Berdasarkan bobot preferensi tersebut diatas maka dilakukan konversi terhadap setiap penilaian terhadapa lternatife yang diangkat dalam uji coba kasus. Berikut ini adalah hasil dari konversi nilai setiap alternative:

Tabel 4. Rating Kecocokan setiap Alternatif Pada Setiap Kriteria

\begin{tabular}{lcccc}
\hline Alternatif & C1 & C2 & C3 & C4 \\
\hline Evan NI Siahaan Xiv & 4 & 4 & 2 & 3 \\
Titin Verianty & 3 & 3 & 4 & 2 \\
Silvia Damayanti & 3 & 4 & 2 & 2 \\
Aan Apriani & 3 & 2 & 4 & 3 \\
Sunarto Suradi & 2 & 4 & 2 & 4 \\
\hline
\end{tabular}

Pada kasus ini ditentukan bahwa bobot preferensi yang digunakan adalah : $\mathrm{W}=(2,3,4,4)$. Sehingga dapat terbentuk matriks keputusan dari table kecocokan adalah sebagai berikut :

$$
x=\left[\begin{array}{llll}
4 & 4 & 2 & 3 \\
3 & 3 & 4 & 2 \\
3 & 4 & 2 & 2 \\
3 & 2 & 4 & 3 \\
2 & 4 & 2 & 4
\end{array}\right]
$$

Untuk menyelesaikan kasusdiatas dengan metode Electre dilakukan dengan beberapa langkah sebagaiberikut :

1. Normalisasi matriks keputusan

$$
\begin{aligned}
& r_{11}=\frac{x_{11}}{\sqrt{\sum_{i=1}^{m} x_{i 1}^{2}}}=\frac{4}{\sqrt{4^{2}+3^{2}+3^{2}+3^{2}+2^{2}}}=\frac{4}{6,8556}=0,5834 \\
& r_{12}=\frac{x_{12}}{\sqrt{\sum_{i=1}^{m} x_{i 2}^{2}}}=\frac{4}{\sqrt{4^{2}+3^{2}+4^{2}+2^{2}}+4^{2}}=\frac{4}{7,81025}=0,51214
\end{aligned}
$$

Dari perhitungan diatas maka didapatkan matriks

$$
R=\left[\begin{array}{llll}
0,5834 & 0,5121 & 0,3015 & 0,4629 \\
0,4375 & 0,3841 & 0,6030 & 0,3086 \\
0,4375 & 0,5121 & 0,3015 & 0,3086 \\
0,4375 & 0,2560 & 0,6030 & 0,4629 \\
0,2917 & 0,5121 & 0,3015 & 0,6172
\end{array}\right]
$$

2. Pembobotan pada matriks yang telah dinormalisasi

$$
V=R W
$$

$$
=\left[\begin{array}{cccc}
0,5834 & 0,51214 & 0,30151 & 0,46291 \\
0,4375 & 0,3841 & 0,6030 & 0,3086 \\
0,4375 & 0,5121 & 0,3015 & 0,3086 \\
0,4375 & 0,2560 & 0,6030 & 0,4629 \\
0,2917 & 0,5121 & 0,3015 & 0,6172
\end{array}\right] \cdot\left[\begin{array}{cccc}
2 & 0 & 0 & 0 \\
0 & 3 & 0 & 0 \\
0 & 0 & 4 & 0 \\
0 & 0 & 0 & 4 \\
0 & 0 & 0 & 0
\end{array}\right]
$$




$=\left[\begin{array}{cccc}1,1668 & 1,5363 & 1,206 & 1,8516 \\ 0,875 & 1,1523 & 2,412 & 1,2344 \\ 0,875 & 1,5363 & 1,206 & 1,2344 \\ 0,875 & 0,768 & 2,412 & 1,8516 \\ 0,5834 & 1,5363 & 1,206 & 2,4688\end{array}\right]$

3. Menentukan himpunan concordance dan discordance index

a. Concordance

Sebuah kriteria dalam suatu alternative termasuk concordance jika :

$C_{k l}=\left\{j, v_{k j} \geq v_{l j}\right\}$, untuk $j=1,2,3 \ldots, n$

$C_{12}=\left\{j, v_{1 j} \geq v_{2 j}\right\}$, untuk $j=1,2,3 \ldots, 4=\{1,2,4$,

$C_{13}=\left\{j, v_{1 j} \geq v_{3 j}\right\}$,untuk $j=1,2,3 \ldots, 4=\{1,2,3,4\}$

b. Disordance

Sebuah kriteria dalam suatu alternatif termasuk discordance jika :

$D_{k l}=\left\{j, v_{k j}<v_{l j}\right\}$, untuk $j=1,2,3 \ldots, n$

$D_{12}=\left\{j, v_{1 j}<v_{2 j}\right\}$, untuk $j=1,2,3 \ldots, 4=\{3\}$

$D_{13}=\left\{j, v_{1 j}<v_{3 j}\right\}$,untuk $j=1,2,3 \ldots, 4=\{\}$

4. Menghitung matriks concordancedan discordance.

a. Menghitung matriks concordance

$$
\begin{aligned}
& \sum_{j \in C_{k l}} w_{j} \\
& C_{12}=W_{1}+W_{2}+W_{4} \\
& C_{12}=2+3+4=9 \\
& C_{13}=W_{1}+W_{2}+W_{3}+W_{4} \\
& C_{13}=2+3+4+4=13
\end{aligned}
$$

Jadi, matriks concordance adalah :

$$
\left[\begin{array}{ccccc}
- & 9 & 13 & 9 & 9 \\
4 & - & 13 & 9 & 4 \\
4 & 9 & - & 5 & 4 \\
7 & 10 & 10 & - & 6 \\
11 & 9 & 11 & 7 & -
\end{array}\right]
$$

b. Menghitung matriks discordance

$$
\begin{aligned}
& d_{k l}=\frac{\max \left\{\left|v_{k j}-v_{l j}\right|\right\}_{j \in D \quad k l}}{\max \left\{\left|v_{k j}-v_{l j}\right|\right\}_{\forall j}} \\
& d_{12}=\frac{\max \left\{\left|v_{1 j}-v_{2 j}\right|\right\}_{j \in D}{ }_{12}}{\max \left\{\left|v_{1 j}-v_{2 j}\right|\right\}_{\forall j}} \\
& d_{12}=\frac{\max \{1,206-2,412\}}{\max \{|1,1668-0,875| ;|1,5363-1,1523| ;|1,206-2,412| ;|1,8516-1,2344|\}} \\
& d_{12}=\frac{\max \{1,206\}}{\max \{0,2918 ; 0,384 ; 0,1206 ; 0,6172\}} \\
& =\frac{1,206}{1,206} \\
& =1 \\
& d_{13}=\frac{\max \left\{\left|v_{1 j}-v_{3 j}\right|\right\} \quad j \in D \quad 13}{\max \left\{\left|v_{1 j}-v_{3 j}\right|\right\}_{\forall j}} \\
& d_{13}=\frac{\max \{0\}}{\max \{|1,1668-0,875| ;|1,5363-1,5363| ;|1,206-1,206| ;|1,8516-1,2344|\}} \\
& d_{13}=\frac{\max \{0\}}{\max \{0,2918 ; 0 ; 0 ; 0,6172\}} \\
& =0 \quad 0 \quad \operatorname{mans}
\end{aligned}
$$

Sehingga matriks discordance menjadi : 


$\left[\begin{array}{ccccc}- & 1 & 0 & 1 & 1 \\ 0,7394 & - & 0 & 1 & 1 \\ 1 & 1 & - & 1 & 1 \\ 0,6370 & 0,6226 & 0,6370 & - & 0,6370 \\ 0,9452 & 0,9753 & 0,5401 & 1 & -\end{array}\right]$

5. Menentukan matriks dominan concordance dan discordance

a. Menghitung nilai matriks dominan concordance

Nilai threshold (ㄷ) adalah :

$$
\begin{aligned}
\underline{c} & =\frac{\sum_{k=1}^{m} \sum_{l=1}^{m} c_{k l}}{m(m-1)} \\
& =\frac{9+13+9+9+4+13+9+4+4+9+5+4+7+10+10+6+11+9+11+7}{5(5-1)} \\
& =\frac{163}{20}=8.15
\end{aligned}
$$

Elemen matriks $\mathrm{F}$ ditentukan sebagai berikut :

$f_{k l}=\left\{\begin{array}{l}1, j i k a c_{k l} \geq c \\ 0, j i k a c_{k l}<c\end{array}\right.$

Sehingga matriks concordance adalah :

$$
F=\left[\begin{array}{ccccc}
- & 1 & 1 & 1 & 1 \\
0 & - & 1 & 1 & 0 \\
0 & 1 & - & 0 & 0 \\
0 & 1 & 1 & - & 0 \\
1 & 1 & 1 & 0 & -
\end{array}\right]
$$

b. Menghitung matriks dominan discordance

Nilai threshold $(\underline{\mathrm{d}})$ adalah

$$
\begin{aligned}
& d=\frac{\sum_{k=1}^{m} \sum_{l=1}^{m} d_{k l}}{m(m-1)} \\
& =\frac{1+0+1+1+0,7394+0+1+1+1+1+1+1+0,6370+0,6226+0,6370+0,6370+0,9452+0,9753+0,5401+1}{5(5-1)} \\
& =\frac{15,7336}{20}=0,78668 \\
& \text { Dan elemen matriks G ditentukan sebagai berikut : } \\
& g_{k l}=\left\{\begin{array}{l}
1, j i k a d_{k l} \geq d \\
0, j i k a d_{k l}<d
\end{array}\right.
\end{aligned}
$$

Dan elemen matriks $\mathrm{G}$ ditentukan sebagai berikut :

Sehingga matriks dominan discordance adalah

$$
G=\left[\begin{array}{ccccc}
- & 1 & 0 & 1 & 1 \\
0 & - & 0 & 1 & 1 \\
1 & 1 & - & 1 & 1 \\
0 & 0 & 0 & - & 0 \\
1 & 1 & 0 & 1 & -
\end{array}\right]
$$

6. Menentukan aggregate dominance matrix

Rumus umum untuk anggota matriks aggregate dominance adalah

$e_{k l}=f_{k l} \times g_{k l}$

$e_{12}=f_{12} \times g_{12}=1 \times 1=1$

$e_{13}=f_{13} \times g_{13}=1 \times 0=0$

Sehingga matriks aggregate dominance adalah

$E=\left[\begin{array}{ccccc}- & 1 & 0 & 1 & 1 \\ 0 & - & 0 & 1 & 0 \\ 1 & 1 & - & 0 & 1 \\ 0 & 0 & 0 & - & 0 \\ 1 & 1 & 0 & 1 & -\end{array}\right]$

7. Eliminasi alternatif yang less favourable

Matriks E memberikan urutan pilihan dari setiap alternative, yaitu jika $e_{k l}=1$ maka alternatif $A_{k}$ merupakan alternatif terbaik dibandingkan $A_{1}$. Sehingga pada matriks E yang memiliki jumlah $e_{k l}=1$ paling sedikit dapat di eliminasi yaitu baris dua, dan empat yang memiliki jumlah paling sedikit maka yang tersisa adalah baris satu, tiga dan lima sehingga alternative pertama atas nama "Evan NI Siahaan Xiv, sunarto sunardi, dan silvia damayanti adalah alternative terbaik dan berhak untuk diangkat menjadi Penyidik Pegawai Negeri Sipil (PPNS). 


\section{KESIMPULAN}

Kesimpulan berdasarkan pembahasan dan evaluasi dari bab terdahulu, maka dapat ditarik kesimpulan sebagai berikut:

1. Mempermudah perhitungan yang digunakan dalam pemilihan penyidik pegawai negeri sipil dengan menggunakan metode Electre.

2. Mempermudah dan mempercepat pihak Balai Wilayah Sungai Sumatera II dalam melakukan proses Pemilihan Penyidik Pegawai Negeri Sipil dengan menggunakan system komputerisasi..

\section{REFERENCES}

[1] I. Saputra, S. I. Sari, and Mesran, "PENERAPAN ELIMINATION AND CHOICE TRANSLATION REALITY ( ELECTRE) DALAM PENENTUAN KULKAS TERBAIK,” KOMIK (Konferensi Nas. Teknol. Inf. dan Komputer), vol. I, pp. 295-305, 2017.

[2] M. Mesran, A. Rizki, and N. Silalahi, "Application of Multi Criteria Supporting Elemination and Choice Translation Reality (ELECTRE) Decision in Determining Scholarship Recipients for Employee Children at PT. Nusira," IJICS (International J. Informatics Comput. Sci., vol. 3, no. 1, Mar. 2019.

[3] I. Dahanum, Mesran, and T. Zebua, "Sistem Pendukung Keputusan Pemilihan Internet Service Provider Menerapkan Metode Elimnation and Choice Translation Reality ( ELECTRE )," Konf. Nas. Teknol. Inf. dan Komput., vol. 1, no. November, 2017.

[4] S. Kusumadewi, S. Hartati, A. Harjoko, and Retantyo Wardoyo, Fuzzy Multi-Attribute Decision Making (FUZZY MADM). 2006.

[5] Kusrini, Konsep dan Aplikasi Sistem Pendukung Keputusan. 2007.

[6] T. Limbong et al., Sistem Pendukung Keputusan: Metode \& Implementasi. Medan: Yayasan Kita Menulis, 2020

[7] "SMART HRD Perusahaan tenang karyawan senang.pdf."

[8] M. Mesran, R. Rusiana, and M. Sianturi, "Decision Support System for Termination of Employment using Elimination and Choice Translation Reality Method," J. Teknol. dan Sist. Komput., vol. 6, no. 4, p. 135, 2018.

[9] A. Yanie et al., "Web Based Application for Decision Support System with ELECTRE Method," J. Phys. Conf. Ser., vol. 1028, no. 1 , 2018 .

[10] Mesran, S. Anita, and R. D. Sianturi, "IMPLEMENTASI METODE ELECTRE DALAM PENENTUAN KARYAWAN BERPRESTASI ( STUDI KASUS : PT . MEGARIMAS SENTOSA )," J. Ris. Sist. Inf. dan Tek. Inform., vol. 3, no. 3, pp. 32-45, 2018.

[11] L. N. Zulita, "Penerapan Metode ELECTRE Dalam Pengambilan Keputusan Pemilihan Produk Unggulan Daerah," J. Inf. Sist. Res., vol. 1 , no. 3, pp. $162-167,2020$

[12] P. Sianturi, M. Mesran, P. Ramadhani, and N. W. Al-Hafiz, "SISTEM PENDUKUNG KEPUTUSAN PENENTUAN PENERIMA BANTUAN OPERASIONAL PENYELENGARAAN ( BOP ) PAUD ( PENDIDIKAN ANAK USIA DINI ) MENERAPKAN METODE ELECTRE ( STUDI KASUS : DINAS PENDIDIKAN KABUPATEN SIMALUNGUN)," KOMIK (Konferensi Nas. Teknol. Inf. dan Komputer), vol. I, no. 1, pp. 20-26, 2017.

[13] L. K. Simanjuntak, T. Y. M. Sihite, M. Mesran, N. Kurniasih, and Y. Yuhandri, "Sistem Pendukung Keputusan SNMPTN Jalur Undangan Dengan Metode Electre,” Jurasik (Jurnal Ris. Sist. Inf. dan Tek. Inform., vol. 3, no. 3, p. 14, 2018

[14] Mesran, Pristiwanto, and D. Sihombing, "IMPLEMENTASI METODE ELECTRE DALAM MENENTUKAN RICE COOKER TERBAIK," J. Telemat., vol. 11, no. 2, pp. 43-54, 2018. 